\title{
CULINARY TRAILS AS AN EXAMPLE OF INNOVATIVE TOURIST PRODUCTS
}

\author{
MONIKA WOJCIESZAK, ${ }^{1}$ MICHAŁ GAZDECKI ${ }^{2}$
}

Poznań University of Life Sciences, POLAND

1 e-mail:mwoj@up.poznan.pl

2 e-mail:migaz@up.poznan.pl

\section{RECEIVED \\ ACCEPTED \\ JEL \\ CLASSIFICATION \\ KEYWORDS}

ABSTRACT
10 July 2018

13 September 2018

$\mathrm{Z} 30, \mathrm{Z} 32$

culinary tourism, culinary trail, innovation

Culinary trails have developed in response to the increasingly common trend of eating out due to changing lifestyles in communities. Travelling inspired by cooking is an interesting phenomenon in Polish tourism. Healthy food and exploration of new culinary regions is increasingly often becoming an important reason for travelling. The aim of the article is to present the definition of culinary tourism in the light of scientific literature and to indicate examples of products of this tourism in Poland. Another aim of the article is to present the essence of culinary tourist trails and show selected examples based on our own study. The second part of the article includes an analysis of the results of our study based on a questionnaire survey conducted on a group of 300 respondents. The summary includes conclusions from the study.

\section{Introduction}

Culinary tourism has developed in response to the increasingly common trend of eating out due to changing lifestyles in communities (López, Gómez, Martín, 2005). Travelling inspired by cooking is becoming a new, innovative form of tourism practised by people who find it important to try and consume foods and drinks in their free time (Mika, 2007). Apart from sightseeing, tourists want to try and consume characteristic specialities of a town or region. 
We can see that Polish tourism in the $21^{\text {st }}$ century is characterised by people's increasing interest in cooking. Woźniczko (2016) stresses the fact that cooking has become a value added in tourist trips.. Thanks to cooking a trip may be even more interesting, because when planning a holiday, people are increasingly often motivated by the wish to experience the native cuisine. Culinary tourism is an opportunity to learn about other cultures through cooking. The trend is becoming increasingly popular among travellers all over the world, including Poland.

\section{Literature review}

\section{Culinapy tourism in literature}

The dynamic development of culinary tourism is reflected by reports in the media, i.e. on the Internet, television and in the press as well as in scientific elaborations (e.g. Kosmaczewska, 2008; Kowalczyk, 2008; Dominik, 2010; Plebańczyk, 2013; Klein-Wrońska, 2014). According to Woźniczko and Orłowski (2010) and Kowalczyk (2005), the term 'culinary tourism' was introduced in reference publications by L. Long in 1998. As she wrote, culinary tourism is an element of culture tourism and cooking is an expression of local culture. It is not necessary to travel to distant countries to be a culinary tourist. According to Long, engagement in culinary tourism is an important aspect, because there may be different degrees of its intensity experienced by tourists. Apart from that, culinary tourism offers a wide range of tourist products. In this context, food products should be attractive enough to encourage tourists to consumption. The spectrum of the definition of culinary tourism is constantly increasing. As Durydiwka (2013) stressed, one of the first definitions of culinary tourism was proposed by Wolf (2004). According to him, culinary tourism consists in travelling to taste ready-made foods and drinks. According to this author, culinary tourism is an undertaking of tourist nature, where making use of the culinary offers of a foreign country or region is an important part of the programme or a decisive motive to make a trip. Culinary tourism requires that high quality food should be offered. It should be made from ingredients and with methods based on the culinary traditions of the target region. Meals should be consumed in an adequate environment. Balińska, Sieczko, Zawadka (2013) note that in culinary tourism foods, drinks and everything that is related with their preparation are attractions of the trip. Culinary tourism encompasses trips made to experience traditional, regional or national dishes, culinary novelties, consumption of local, regional and national drinks as well as products protected by the EU regulations (protection of the name of origin, geographical mark and guaranteed traditional speciality). Orłowski, Woźniczko (2015, p. 124) emphasise that this type of tourism gives satisfaction to participants because they can personally enjoy the experience of new flavours and aromas. They take part in culinary events, follow culinary routes, visit restaurants and museums. Similarly, Majewski (2008) notes that culinary tourism involves learning about, evaluating and consuming local food products, participating in the food production process and gaining outstanding culinary experience. In this sense culinary tourism can be interpreted as any tourist experience where one can evaluate and consume the foods and drinks which reflect local, regional and national cuisines as well as the culture and heritage of a particular place. There are different definitions of culinary tourism in literature, e.g. gastronomic tourism, whose aim is to reach a particular place or source offering unique and wanted food, e.g. a restaurant (Kivela, Crotts, 2006). Culinary tourism involves learning about the local cuisine, recipes and tools as well as participation in the preparation of food (Plebańczyk, 2013). Generally, culinary tourism consists in acquiring knowledge about the dishes and culinary products of a particular region, which may be combined with sightseeing, learning about the culture and nature . Local culinary patriotism is more and more noticeable in Poland. It is manifested by culinary trails, culinary incubators (local food processing incubators), culinary events, e.g. Potato Day, Pumpkin Day, fair 
events, e.g. Regional Tastes, culinary festivals, museums, agritourist farms and rural tourist facilities promoting culinary heritage. Sala (2016) indicated that the development of culinary tourism is affected by numerous factors, such as the promotion of different cuisines in the media, decreasing popularity of fast food outlets, the development of restaurants offering ethnic and folk food, the development of a large group of multicultural tourists, individualised behaviours of food and tourist market travellers and increasing importance of traditional.

\section{Culinary trail as product innovation}

J. Tomczak (2013) notes that it is necessary to start considerations about culinary trails by answering the question whether the culinary trail is a theme or tourist trail. The literature provides numeorus definitions of the tourist trail. The Polish Tourist and Sightseeing Society defines the tourist trail as a route for making trips, which is marked with standard signs and equipped with information devices which guarantee that a tourist with any skills and experience can walk along the route safely and undisturbed at any time of the year, regardless of the weather conditions. As far as the theme trail is concerned, it is necessary to stress the fact that it mainly refers to the main idea and the theme it presents. According to Tomczak (2013), the culinary trail should be considered through the prism of the theme trail. The author thinks that the theme trail that includes elements of interest to culinary tourists should be regarded as a culinary theme trail. Apart from that, the theme trail concentrates numerous elements, such as the selection of facilities, trail authenticity, field layout and the route marking method, means of promotion, addressees, additional tourist attractions related with the trail and most importantly, the trail theme. According to publications, there are more than twenty theme trails in Poland (Table 1). These are the undertakings of the owners of restaurants, agritourist farms and facilities offering places to sleep.

Table 1. Selected culinary trails in Poland

\begin{tabular}{|c|c|}
\hline Name of trail & Main theme \\
\hline $\begin{array}{l}\text { The Culinary Stops } \\
\text { of the Suwałki and } \\
\text { Masuria Regions }\end{array}$ & $\begin{array}{l}\text { 'The Culinary Stops' trail was developed by the Suwałki Chamber of Agriculture and Tourism, a member of the Tourist Brands } \\
\text { Cluster of Eastern Poland, as part of the EGO SA (Ełk, Gołdap, Olecko, Suwałki, Augustów) cooperation platform - the project } \\
\text { joining Eastern Masuria and the Suwałki Region. Local cooks and housewives offer tourists dishes such as: cepelinai, potato pies } \\
\text { and sausages, lentil bread, dumplings, kininai, cenakai, praskuc, karmuszka, ślizyk. Many inns, restaurants and homes along the } \\
\text { trail offer bread baked with calamus, tree cake and anthill cake. }\end{array}$ \\
\hline Goose Culinary & The Goose Culinary Trail was established to keep the old Polish tradition of goose meat consumption in Kuyavian-Pomeranian \\
\hline Trail & $\begin{array}{l}\text { Voivideship. This is one of the most important goose-breeding areas in Poland, where white geese, highly appreciated by } \\
\text { gourmets, are bred. The trail project is implemented by the Kuyavian-Pomeranian Tourist Organisation under the project 'I like } \\
\text { eating in Kuyavia-Pomerania'. At present there are } 17 \text { restaurants along the trail. }\end{array}$ \\
\hline Plum Trail & $\begin{array}{l}\text { It is located in Lesser Poland. It offers tourist events, such as Prune Festival, Let's Meet on the Prune Trail (summer), Plum, Honey } \\
\text { and Cheese Festival, From Grain to Country Speciality. Tourist visitors can see and explore the Noble Plum Village. Apart from } \\
\text { 'Suski sechlońskie' (local product) tourists can taste home-made kompot, plum butter and yeast cake baked by housewives. }\end{array}$ \\
\hline $\begin{array}{l}\text { Herbal Aromas } \\
\text { of Lesser Poland } \\
\text { Countryside }\end{array}$ & $\begin{array}{l}\text { There are } 19 \text { attractively located agritourist facilities along the trail. They were carefully selected from numerous agritourist farms } \\
\text { in Lesser Poland. They specialise in the growing and wide use of herbs. The owners of herbal gardens grow lovage, tarragon, } \\
\text { mint, oregano, thyme, rosemary, sage, marjoram, melissa and others. Many farms also offer herbal baths, massage and aroma } \\
\text { therapy. The trail was established by the Sącz Tourist Organisation. }\end{array}$ \\
\hline
\end{tabular}

Source: compiled by the authors.

The product innovation of culinary trails is complex. It combines a few elements, i.e. tourists, farm and restaurant owners and food producers. First of all, the aim of culinary trails is to increase the awareness of agritourist farm and restaurant owners about the significance of the local brand for the development of entrepreneurship in the 
local market. Second of all, the creation of culinary specialities and promotion of local products build the portfolio of a region. The education of farm and restaurant owners to improve the quality of food and services is another important element of product innovation. It is essential for local producers, farmers and food processing enterprises to cooperate in order to build a culinary trail. The engagement of individual elements in the chain is crucial to the success and popularity of a particular culinary trail. The creation of a strong, local brand as well as increasing producers and consumers' awareness of ecological, cultural and social values of local products offered along the trail are important elements of a tourist trail.

\section{Products of culinary tourism - our study}

The awareness of the concept of culinary tourism depends on practising this form of tourism and it may determine interest in it. As results from the questionnaire survey, the index referring to the awareness of the concept of culinary tourism amounts to $57 \%$. Apart from that, the respondents correctly identified the concept and were able to describe it. They associated culinary tourism with culinary trips (32\%), regional food $(27 \%)$, cooking (22\%) and healthy diet (19\%).

Table 2. The most popular products of culinary tourism in three periods of time (\%)

\begin{tabular}{|c|c|c|c|c|c|}
\hline \multicolumn{2}{|l|}{ Past } & \multicolumn{2}{|l|}{ Present } & \multicolumn{2}{|l|}{ Future } \\
\hline Regional food [tasting] & 23 & Tasting regional food during trips & 48 & $\begin{array}{l}\text { Tourist trips to vineyards, culinary } \\
\text { incubators }\end{array}$ & 32 \\
\hline Cooking & 15 & $\begin{array}{l}\text { Purchasing food products from } \\
\text { agricultural or agritourist farms }\end{array}$ & 32 & Participation in culinary events & 28 \\
\hline Culinary trips, e.g. harvest festivals & 10 & Learning to cook regional dishes & 12 & Education & 27 \\
\hline Healthy diet & 7 & Organic farming & 6 & Sightseeing tours along culinary trails & 13 \\
\hline
\end{tabular}

Source: compiled by the authors.

As results from the research (Table 2), in the past the respondents mostly tasted regional food, made culinary trips and cooked dishes. At present the respondents taste regional food during trips, buy food products from agricultural or agritourist farms and participate in culinary events. In the future the respondents would like to visit vineyards, participate in culinary events and acquire knowledge based on culinary tourism. The respondents showed their interest in culinary trails - $13 \%$ would like to make a trip along a culinary trail in the nearest future. According to $36 \%$ of the respondents (men $-22 \%$, women $-78 \%$ ), regional restaurants and inns are the biggest attraction of culinary tourism (Figure 1). 


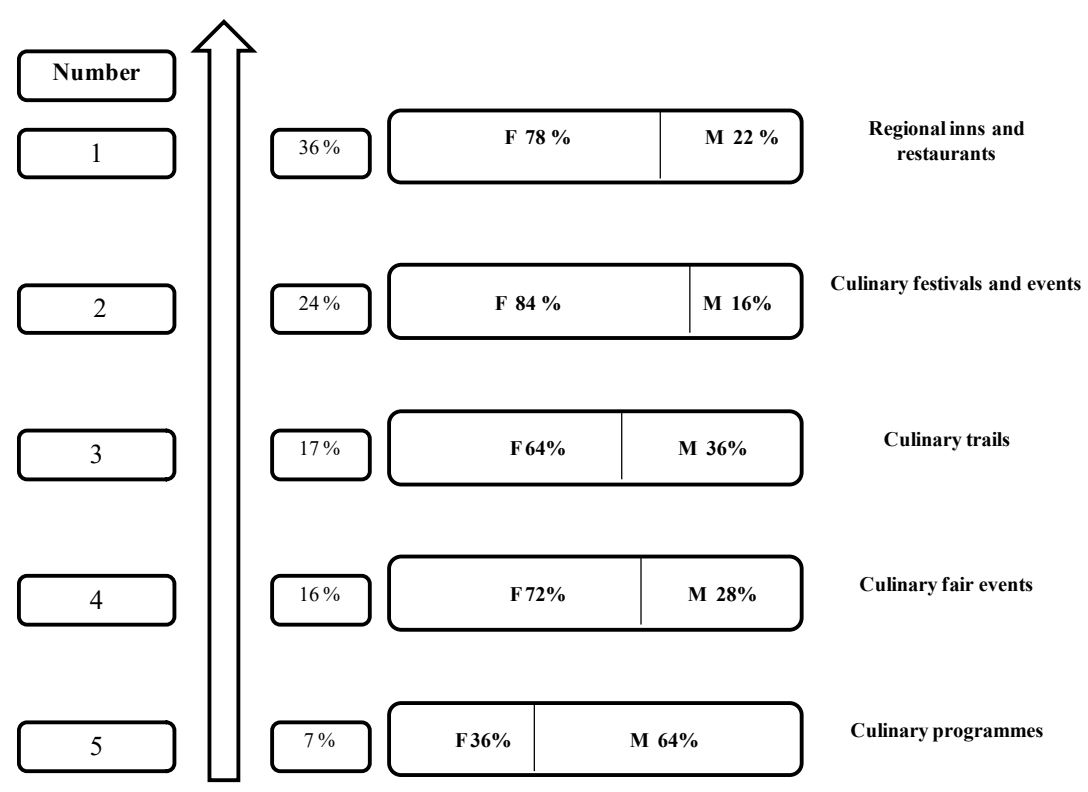

Figure 1. The hierarchy of culinary tourist products and their popularity among men and women

Source: compiled by the authors.

According to the men (64\%), culinary programmes are the most attractive form of culinary tourism. The women's opinion was different. They think that culinary festivals and events, regional inns and restaurants as well as culinary fair events are the most interesting attractions of culinary tourism. When asked about trends in the development of culinary tourism, the respondents indicated that it is necessary to provide more information about it (Figure 2).

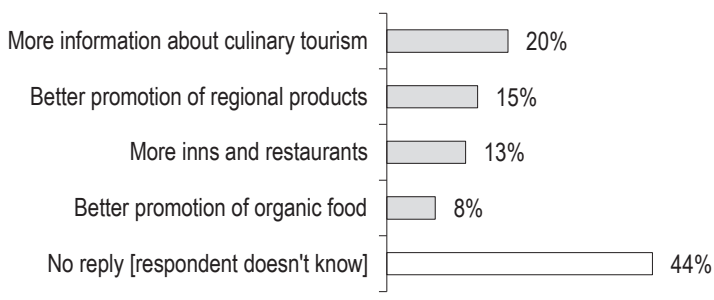

Figure 2. The trend of development of culinary tourism

Source: compiled by the authors.

The respondents declared that it was necessary to promote regional products and organic food. More than $40 \%$ of the respondents could not indicate any trend of development of culinary tourism. It was interesting to ask the respondents about culinary trails. More than $64 \%$ declared that they had heard of this product of culinary tourism, but only $21 \%$ were able to list the themes of culinary trails. Only $9 \%$ of the respondents were able to name one culinary trail. As results from the analyses, tourists have minimal awareness of the existence of some culinary trails. 
For example, only $12 \%$ of them knew the following culinary trails: the Herbal Aromas of Lesser Poland Countryside and the Tradition and Taste Trail.

Table 3. The respondents' awareness of selected culinary trails

\begin{tabular}{lc}
\hline \multicolumn{1}{c}{ Name of trail } & $\begin{array}{c}\text { Respondents' awareness } \\
(\%)\end{array}$ \\
\hline Oscypek Cheese Trail & 67 \\
Tastes of the Tatra Foothills & 61 \\
Culinary Poznań & 52 \\
Goose Culinary Trail & 45 \\
Gdynia Centre Culinary Trail & 34 \\
Masovian Noble Bowl & 34 \\
Sandomierz Wine Trail & 34 \\
Culinary Stops of the Suwałki and Masuria Regions & 23 \\
Gdańsk-Pomeranian Culinary Prestige & 22 \\
Białystok Culinary Trail & 21 \\
Plum Trail & 17 \\
Tradition and Taste Trail & 12 \\
Herbal Aromas of Lesser Poland Countryside & 12 \\
\hline
\end{tabular}

Source: compiled by the authors.

The Oscypek Cheese Trail, the Tastes of the Tatra Foothills and the Culinary Poznan were known to more than $50 \%$ of the respondents. The high awareness of these trails may have resulted from good information and promotion. Apart from that, tourists travelling in the mountains often choose the restaurants and inns that offer traditional regional products. The Goose Culinary Trail, the Gdynia Centre Culinary Trail, the Masovian Noble Bowl and the Sandomierz Wine Trail are not only interesting and abundant in the beauty of nature but they also offer healthy, organic food. A wide group of tourists is invited not only to visit interesting places in the city and admire nature but also to enjoy culinary attractions. The respondents were also asked about the source of information about tourist trails. More than $30 \%$ of the respondents received this information from the websites of tourist organisations, $26 \%$ - from the websites of individual trails, $17 \%$ - from leaflets and posters, $14 \%$ - from travel agencies (tourist information offices) in the towns they visited. It was interesting to find out how much money tourists were ready

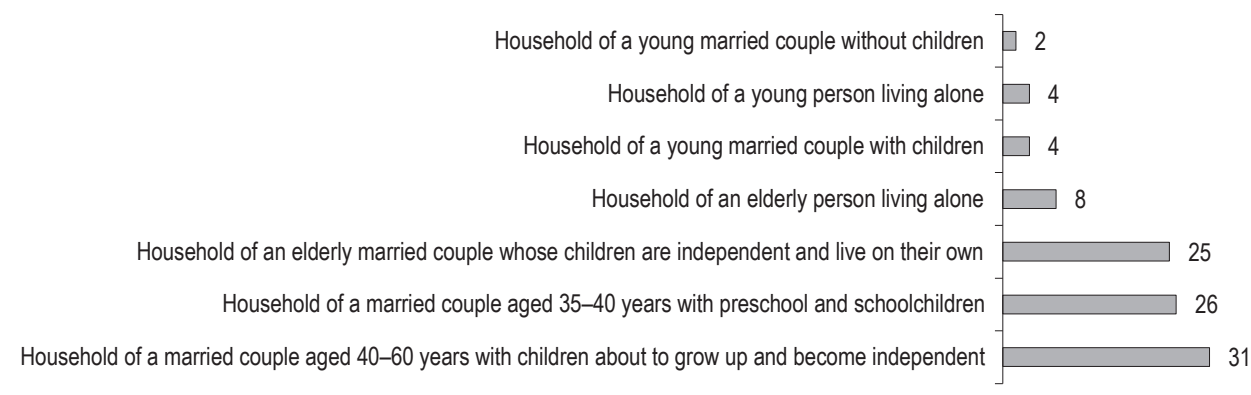

Figure 3. The development phase of the respondents' households and their interest in culinary tourism Source: compiled by the authors. 
to spend on culinary tourism. As $67 \%$ of the respondents declared, they were ready to spend $350-500$ PLN. $27 \%$ were ready to spend less than $350 \mathrm{PLN}$. Only $5 \%$ were ready to spend more than $500 \mathrm{PLN}$. The relation between the development phase of the respondents' households and their interest in culinary tourism was also investigated.

As results from the analysis of the development phase of the respondents' households, married couples aged 40-60 years, whose children were about to grow up and become independent, were the most regular users of culinary tourist products. They were followed by married couples aged 35-40 years with preschool and schoolchildren as well as elderly married couples whose children are independent and live on their own. Culinary tourist products were the least popular among young married couples without children, people living alone and young married couples with children under the age of 3 .

\section{Conclusions}

Culinary tourism is developing in Poland. It could be the main reason for travelling or it may be the basis for supplementary tourist products.The research showed minimal awareness of the concept of culinary tourism, but the respondents who knew it, described it correctly. The respondents' declarations indicate that in the future the interest in this type of tourism may grow. In consequence, there may be positive economic results for the tourist sector. We can expect the demand for new tourist products, the development of catering facilities, new jobs, lower unemployment, higher income in local budgets, etc. The existence and development of culinary trails may help to promote regions and the cultural heritage of Poland.

\section{References}

Balińska, A., Sieczko, A., Zawadka, J. (2013). Wybrane problemy rozwoju turystyki. Warszawa: SGGW.

Durydiwka, M. (2013). Turystyka kulinarna - nowy (?) trend w turystyce kulturowej. In: M. Derek (ed.), Culinary Tourism (pp. 9-30). Warszawa: Uniwersytet Warszawski.

Kivela, J., Crotts, J.C. (2006). Tourism and Gastronomy. Gastronomy's Influence on How Tourists Experience a Destination. Journal of Hospitality \& Tourism Research, 3 (30).

Mikos v. Rohrscheidt, A. (2008). Kulturowe szlaki turystyczne - próba klasyfikacji oraz postulaty w zakresie ich tworzenia i funkcjonowania. Turystyka Kulturowa, 2, 17-32.

Orłowski, D., Woźniczko, M. (2010). Gastronomia folklorystyczna ijej wykorzystanie w turystyce. In: Z. Dolatowski, D. Kołożyn-Krajewska (eds.), Gastronomia w ofercie turystycznej regionu (pp. 323-346). Częstochowa: Wyższa Szkoła Hotelarstwa i Turystyki.

Orłowski, D., Woźniczko, M. (2015). Turystyka kulinarna na wiejskim rynku turystycznym. In: W. Kamińska (ed.), Innowacyjność w turystyce wiejskiej a nowe możliwości zatrudnienia na obszarach wiejskich (pp. 121-142). Warszawa: Wydawnictwo Studia KPZK PAN.

Plebańczyk, K. (2013). Turystyka kulinarna w kontekście zrównoważonego rozwoju w kulturze - perspektywy dla Polski. Turystyka Kulturowa, 10, 14-34.

Sala, J. (2016). Rynek żywnościowy jako element kształtujący atrakcyjność i tożsamość turystyczną Małopolski. Ekonomiczne Problemy Turystyki, 3 (35), 209-222.

Stasiak, A. (2013). Nowe przestrzenie i formy turystyki w gospodarce doświadczeń. Turyzm, 2 (23), 65-74.

Tomczak, J. (2013). Szlak kulinarny jako przykład szlaku tematycznego. Prace i Studia Geograficzne, 53, 47-52.

Wolf, E. (2002). Culinary tourism: a tasty economic proposition. Portland: International Culinary Tourism Association.

Cite this article aS: Wojcieszak, M., Gazdecki, M. (2018). Culinary Trails as an Example of Innovative Tourist Products. European Journal of Service Management, 3 (27/1), 357-363. DOI: 10.18276/ejsm.2018.27/1-46. 